\title{
Residents' Perceptions of the Impacts of Tourism Development: Empirical Evidence from UAE
}

\author{
Maryam Taha Mannaa \\ College of Arts, Humanities and Social Sciences, University of Sharjah, Sharjah, UAE; Faculty of \\ Tourism and Hotels, Alexandria University, Alexandria, Egypt
}

\begin{abstract}
The United Arab Emirates is one of the most prosperous countries in the Middle East as regards travel and tourism development. In 2018, the net contribution of the travel and tourism industry represented $11.1 \%$ of UAE GDP. COVID-19 pandemic has had a major negative impact on the tourism industry in the UAE as well as around the world. The number of international tourists has dropped sharply and big events like Dubai Expo 2020 have been canceled or postponed. Considering COVID-19 pandemic and its impact on travel and tourism industry worldwide, the aim of the present study is to examine the perception of UAE residents about the economic, socio-cultural and environmental impacts of tourism. The study also aims to assess the influence of residents' perceptions towards tourism impacts on their support for future tourism development. The study used the quantitative method to test the research hypotheses. 362 usable responses were collected from five different emirates in UAE. Data were analyzed using the advanced structural equation modeling (SEM) technique. The findings indicated a major disparity between locals' and expatriates' perceptions of the tourism impacts. Nevertheless, both groups continue to support the development of tourism in the midst of the COVID-19 pandemic.
\end{abstract}

Keywords: UAE, Residents' Perceptions, Tourism Development, Tourism Impacts, Social Exchange Theory, COVID-19.

\section{Introduction}

The tourism industry is considered one of the key engines of economic diversification in developing countries (UNWTO, 2017; Long \& Kayat, 2011). Tourism can bring diverse privileges to locals such as job opportunities, development of public facilities, promotion of local entrepreneurship and local economic growth (Hammad, Ahmad \& Papastathopoulos, 2017; Long \& Kayat, 2011; Simao \& Mosso, 2013). Besides the usual positive economic, social, and environmental benefits of tourism, tourism also has some negative impacts on societies (Long \& Kayat, 2011; Simao \& Mosso, 2013). An equitable distribution of benefits among stakeholders is the best way to accomplish sustainable tourism development that ensures financial gains and protects the host community's socio-cultural and environmental facets (Simao \& Mosso, 2013). Residents are essential stakeholders in the development of tourism. Their expectations and attitudes towards tourism impacts are likely to be a significant planning and policy factor (Hammad et al., 2017; Papastathopoulos, Ahmad, Al Sabri \& Kaminakis, 2019; Özel \& Kozak, 2017; Mohammadi, khalifah \& Hosseini, 2010; Brunt \& Courtney, 1999). Research has started to report the perceptions of residents in the developed countries. However, similar studies in developing countries are few (Almeida-García et al., 2016; Woosnam, 2019; Nyaupane, Lew \& Tatsugawa, 2014; Hammad et al.2017). This study responds to many calls for further research necessary to increase the understanding of residents' prospects for tourism impacts in developing countries (Mohammadi et al., 2010). UAE is one of the Middle East most popular tourist destinations, so this research is extremely relevant for government officials and tourism planners to understand the expectations of residents about the impact of tourism expansion and to assess their level of support for it. 
Some previous studies explored the perceptions of the residents about the effect of tourism growth in the UAE and their level of support for it (Papastathopoulos et al., 2020; Hammad et al., 2017). Some of these studies have recommended that further work to be done to verify the findings and to cover further regions within the UAE. The contribution of this research is that it examines the perceptions of residents during the COVID-19 pandemic era. The data analysis in the current study examines the influence of the epidemic on people's perceptions of the tourism development.

Consequently, the key objectives of this study are: to investigate residents' perceptions of the impact of tourism development in UAE; to assess residents' level of support for tourism growth; to compare the results of this study with previous studies in the UAE; and to analyze whether the pandemic situation would alter residents' perceptions of the impact of tourism development in a specific region.

\section{Literature Review}

The tourism sector has made a significant contribution to most of the Gulf Cooperation Council (GCC) countries non-oil economic growth. GCC countries had attempted seriously to reduce dependence on crude oil exports and diversify their economies by stablishing tourism development (Mubasher, 2020).

The United Arab Emirates (UAE) is an emerging GCC country that has relied on oil revenues as its major source of income over the last four decades. The UAE used oil revenues to build modern infrastructure and to establish service industries, including tourism, to ensure its longterm economic stability. In the last two decades, the UAE has managed to become one of the top tourist destinations in the Middle East, drawing millions of visitors from all over the world each year (Al Asoomi, 2015; Sutton, 2016). The UAE, which ranked 29th worldwide, remains by far the region's most prosperous country in terms of travel and tourism. The nation hosted 14.4 million international tourists in 2015, 4 million more than two years before. In 2019, Dubai itself registered a total of 16.73 million visitors (Agence France-Presse (AFP), 2020). The UAE offers an outstanding business environment with advanced ICT readiness (15th worldwide) and one of the best air transport infrastructures in the world (3rd worldwide) in terms of both accessibility and service quality. It is among the safest destinations in the world (2nd worldwide), and has a well-built network of hospitality and recreational facilities (27th worldwide) (Travel and tourism competitiveness report, 2017).

The net contribution of the travel and tourism industry to the UAE GDP in 2016 was AED 159.1 billion, which represented 12.1 per cent of its GDP (World Travel and Tourism Council, 2017). In 2018, tourism sector contributed AED164.7 billion or 11.1 percent to the UAE's GDP (Emirates News Agency,2019). The travel and tourism sector directly funded 317,500 jobs in the UAE, which represents 5.4 per cent of total employment in 2016. Before the COVID-19 pandemic, this number was expected to grow by 2.4 per cent per annum to 410,000 jobs, which would constitute 5.9 per cent of overall employment in 2027 (World Travel and Tourism Council, 2017). In 2016, the net contribution of the travel and tourism industry to employment, including indirectly supported workers, amounted to 10.4 percent of the overall workforce equals to 617,500 jobs. This figure was projected to grow by $2 \%$ per annum to 770,000 workers in 2027 before the COVID-19 pandemic, which would constitute $11.1 \%$ of overall employment (World Travel and Tourism Council, 2017).

COVID-19 has had a nagative impact on the tourism sector in the UAE, as several major events have been canceled or postponed, including Art Dubai 2020 and Dubai Expo 2020, which have been expected to attract millions of visitors. Globally, visitor arrivals are expected to decline between $58 \%$ and $78 \%$, decrease foreign revenues by $\$ 874$ billion and $\$ 1,175$ billion, and put up 
to 75 million people out of work (Mubasher, 2020). As per the UAE, international tourism revenue is projected to fall by $\$ 15$ billion to $\$ 6.4$ billion in 2020 , compared to $\$ 21.4$ billion in 2019 due to the coronavirus (COVID-19) epidemic, dropping by $70 \%$.

Dubai, the economic capital of UAE has been ranked as the fourth most visited city in the world for five years in a row, according to Mastercard's Global Destination Cities Index (GDCI) 2019 (Mastercard, 2019). The city welcomed 15.93 million international overnight visitors in 2018. At the end of April 2020, the Dubai Chamber of Commerce investigated 1,228 CEOs across a wide range of tourism sectors during the tightest lockdown period in the city. About half of the restaurants and hotels surveyed were predicted to be out of operation in May 2020 alone (Turak, 2020). Around $74 \%$ of travel and tourism firms said they planned to close at that time, and $30 \%$ of shipping, storage and communications firms predicted the same misfortune. Many hotels were vacant, there have been no inbound passenger flights for non-UAE nationals since 24 March 2020 (Turak, 2020). In that growing instability, companies in the UAE's seven emirates, like anywhere else in the country, were cutting wages, placing workers on unpaid leave and reducing personnel levels. As the UAE depends on expatriate population for 80 percent of its economy, the threats are much greater. Residents returning to their homeland would certainly reduce the consumer base required to make economic recovery possible. (Turak, 2020).

\section{UAE population}

UAE is a multicultural destination, with a substantial number of expatriate people drawn to the country following oil exploration compared to a limited number of natives. The UAE allocated its oil returns in large development projects, health care facilities, education programs, and housing schemes that turned its desert into modern cities. This huge development projects required a significant number of personnel and skills not available in the UAE that attracted a number of neighboring and foreign expatriates. In short time, the UAE succeeded in achieving phenomenal economic growth (Hammad, Ahmad \& Papastathopoulos, 2019). The expatriates represent a rising UAE population, and have been the main contributor to the workforce. In 2018, nationals made just eight per cent of the UAE workforce (Kumar, 2018). Expatriates have become a cohesive part of the UAE community. Hence, it is important to include expatriates in the analyses of residents' views of tourism impacts. Nationality is among the main demographic factors influencing an individual's prospects (Papastathopoulos et al., 2020). Understanding the discrepancies between the perceptions of different groups of residents will provide policymakers and tourism partners with valuable information for future planning of the tourism sector (Hammad at al., 2019).

\section{Tourism Impacts}

The development of tourism has both positive and negative consequences for destinations. In the positive side, tourism can create new job opportunities for local people, enhance public services and amenities, reinforce business networks in communities, increase the quality of life for locals, help conserve landmarks and archeological sites, and maintain the heritage and cultural pride of societies (Almeida-García et al., 2016, Woosnam et al., 2019). Tourism, though, can also create negative environmental, economic and socio-cultural consequences, with seasonality being one of the most important adverse impacts. Public and leisure infrastructures are crowded during the high tourist season, road congestion and parking issues arise, which often trigger inconvenience for local people (Woosnam et al., 2019; Ukaegbu, Carr \& Okpoko, 2019). Tourism can increase quality of life (Woosnam et al., 2019; Ukaegbu et al., 2019), as well as drug and alcohol problems (Diedrich \& García, 2009; Almeida-García et al., 2016); serious environmental damage and substantial increases in waste and pollution (Dyer et al., 2007). This tourism-related 
inconvenience and collateral damage could generate and reinforce negative attitudes towards tourism among the local population.

Negative attitudes among locals may be a hindrance to tourism sustainable development. Tourism industry 's success relies on local attractions and the local residents' hospitality (Rezaei, 2017; Özel \& Kozak, 2017). The hostile behavior of residents towards tourists could be a factor in curbing the tourism sector; by contrast, a friendly attitude could support the development of tourism. Generally speaking, tourists tend to be reluctant to visit destinations where they feel unwelcome (Ukaegbu et al., 2019; Diedrich \& García, 2009). So, the support of residents is a key factor in the development of tourism.

Perceptions of residents regarding the impacts of tourism growth have been studied in many areas, and there is some agreement that the major impacts are economic, socio-cultural and environmental (Almeida-García et al., 2016; Singh, 2013; Li \& Bai, 2005; Hale \& Kozak, 2017; Lundberg, 2017; Stylidis et al., 2014; Long \& Kayat, 2011; Mohammadi et al., 2010).

\section{Social Exchange Theory}

The theory of social exchange (Ap 1992) is one of the many theories that were developed in an effort to explain and explore the attitude of the host community towards tourism. The theory of social exchange is extremely prevalent among scholars (Hammad et al., 2017; Long \& Kayat, 2011; Özel \& Kozak, 2017; Hale \& Kozak, 2017; Woosnam et al., 2019; Rasoolimanesh, 2015). This is a general sociological theory, as stated by Ap (1992), highly associated with the exchange of resources between individuals and groups in a setting of interaction. Generally, an individual who recognizes more benefits from an exchange than costs is inclined to take it favorably. On the contrary, it is probable that someone who perceives more costs than benefits will evaluate it negatively. Thus, individuals' satisfaction with an interaction is achieved by the assessment of outcomes, which can be both economic, social, and the interaction itself (Özel \& Kozak, 2017; Long \& Kayat, 2011).

From a tourism viewpoint, the principle of social exchange suggests that residents evaluate the costs and benefits resulting from tourism and, if their evaluation is favorable, their attitude towards the industry should be favorable and they will support this type of exchange (Hammad, et al., 2017; Long \& Kayat, 2011; Özel \& Kozak, 2017; Hale \& Kozak, 2017; Woosnam et al., 2019). The research has a similar emphasis and this is why the theory of social exchange has been used as a theoretical basis for the study.

\section{Research hypotheses}

After reviewing the literature related to the tourism impacts, the following research hypotheses were formulated:

H1. The residents' perceptions of tourism positive economic impacts are positively affecting respondents' overall perceptions of tourism impacts.

H2. The residents' perceptions of tourism negative economic impacts are negatively affecting respondents' overall perceptions of tourism impacts.

H3. The residents' perceptions of tourism positive social impacts are positively affecting respondents' overall perceptions of tourism impacts.

H4. The residents' perceptions of tourism negative social impacts are negatively affecting respondents' overall perceptions of tourism impacts.

H5. The residents' perceptions of tourism positive environmental impacts are positively affecting respondents' overall perceptions of tourism impacts.

H6. The residents' perceptions of tourism negative environmental impacts are negatively affecting respondents' overall perceptions of tourism impacts. 
H7. The overall respondents' perceptions of tourism impacts are positively influencing their perceptions towards tourism development

\section{Methodology}

\section{Research method and Data collection}

The present study uses the deductive approach based on the quantitative method to test the research hypotheses. Data were collected using a self-administrative questionnaire, conducted between April and June 2020. The survey consisted of three sections, with the first covers the subjects' demographics. The second section investigates subjects' perceptions of tourism's economic, sociocultural and environmental impacts. The third section examines subjects' general support for tourism development in UAE. The survey included six independent variables. Three of these variables are: positive economic, sociocultural and environmental impacts of tourism development. The other three variables are: negative economic, sociocultural and environmental impacts. The seventh variable is a dependent variable that examines the participants' general support for tourism development. The variables and the items under them were derived from previous studies dealing with residents' perceptions of tourism's impacts (Singh, 2013; Li \& Bai, 2005; Hale\& Kozak, 2017; Lundberg, 2017; Stylidis et al., 2014; Long \& Kayat, 2011; Mohammadi et al., 2010). Items were measured using a five-point, Likert-type scale anchored by strongly disagree and strongly agree.

The questionnaire was written in English and translated into Arabic, the official language of the UAE and the mother tongue of locals. Both Arabic and English versions of the survey were pretested amongst colleagues with master's or $\mathrm{PhD}$ degrees for validity concerns. The final version of the survey was constructed after minor changes incorporated based on comments received. The survey was available in both Arabic and English versions to suit all residents of the UAE (locals and expatriates). The questionnaire was sent to subjects in an online version only due to the COVID- 19 precautionary measures. Simple Random sampling was used to collect data from respondents. The survey was collected from residents of emirates of Abu Dhabi, Dubai, Sharjah, Ajman, and Ras Al - Khaimah. In total, 371 were collected, of which 362 were valid for analyses (178 responses from UAE citizens versus 184 responses from expatriates).

\section{Findings}

Defining the principal terms used in the findings is crucial for the significance and clarity of the results. These terms include citizens (or Emiratis) and expats (or expatriates). The term citizen or locals applies to individuals holding Emirati citizenship. The term Emiratis, nationals and citizens are similar in meaning and are used interchangeably in this study. Expatriates or expats refers to non-national individuals who reside in the UAE for any reason (i.e. work, study, retirement). In this study, expats refer to individuals who live in the UAE, regardless of their nationality or length of residency.

\section{Respondents' profile}

This section looks at the descriptive statistics of the respondents. Table (1) shows the respondents' demographic profile. Looking at Table (1), the collected responses from citizens are 178, of which $38.2 \%$ are between 18 and 25 years, $29.2 \%$ are between 36 and 45 years, and $23.6 \%$ are between 26 and 35 years old. As for expats, the collected responses are 184, of which the majority (45.1\%) is between 36 and 45 years old, and $31 \%$ are between 18 and 35 years.

Table 1: Respondents' profile

\begin{tabular}{|l|c|c|c|}
\hline Demographics & Citizens \% (N=178) & Expats \% (N=184) \\
\hline \multirow{3}{*}{ Age (years) } & $18-25$ & 38.2 & 16.3 \\
\cline { 2 - 4 } & $26-35$ & 23.6 & 14.7 \\
\cline { 2 - 4 } & $36-45$ & 29.2 & 45.1 \\
\hline
\end{tabular}


International Journal of Heritage, Tourism and Hospitality Vol. (14), No. (1), June, 2020

\begin{tabular}{|c|c|c|c|}
\hline \multicolumn{2}{|l|}{ Demographics } & \multirow{2}{*}{$\begin{array}{c}\text { Citizens \% }(\mathbf{N}=\mathbf{1 7 8}) \\
9.0\end{array}$} & \multirow{2}{*}{$\begin{array}{c}\text { Expats \% }(\mathbf{N}=\mathbf{1 8 4}) \\
21.7\end{array}$} \\
\hline & $46-60$ & & \\
\hline & Above 60 & - & 2.2 \\
\hline \multirow[t]{2}{*}{ Gender } & Male & 27.5 & 34.8 \\
\hline & Female & 72.5 & 65.2 \\
\hline \multirow{5}{*}{$\begin{array}{l}\text { Residence } \\
\text { period }\end{array}$} & Less than a year & - & 25.1 \\
\hline & $6-10$ & - & 11.4 \\
\hline & $11-15$ & - & 21.7 \\
\hline & $16-20$ & - & 20.1 \\
\hline & More than 20 & - & 21.7 \\
\hline \multirow[t]{4}{*}{ Marital status } & Single & 40.4 & 25.0 \\
\hline & Married & 57.9 & 72.8 \\
\hline & Divorced & 1.7 & 1.1 \\
\hline & Widow & - & 1.1 \\
\hline \multirow{3}{*}{ Education } & High school & - & 3.3 \\
\hline & University & 19.7 & 81.5 \\
\hline & Post graduate & 80.3 & 15.2 \\
\hline \multirow{6}{*}{ Monthly income } & Less than 10000 AED & 8.4 & 14.1 \\
\hline & $10000-20000$ & 25.3 & 19.6 \\
\hline & $21000-30000$ & 30.3 & 23.4 \\
\hline & $31000-40000$ & 10.1 & 17.9 \\
\hline & $41000-60000$ & 14.6 & 12.5 \\
\hline & More than 60000 & 11.2 & 12.5 \\
\hline \multirow[t]{5}{*}{ Job } & Unemployed & 18.5 & 29.9 \\
\hline & Student & 29.2 & 15.8 \\
\hline & Tourism-related job & 5.1 & 4.3 \\
\hline & Non-tourism-related job & 44.9 & 49.5 \\
\hline & Retired & 2.2 & .5 \\
\hline
\end{tabular}

It is shown that the majority of citizen and expats' respondents are females $(72.5 \%$ and $65.2 \%$ respectively). The residence period for expatriates ranges between more than 20 years $(21.7), 11$ 15 years $(21.7 \%), 16$ - 20 years $(20.1 \%), 6$ - 10 years $(11.4 \%)$ and $(25.1 \%)$ for less than a year. The majority of citizens and expats are married $(75.9 \%$ and $72.8 \%$ respectively). While most citizens have a postgraduate education (80.3\%), the majority of expats have a university qualification (81.5\%). As for the monthly income, the majority of citizens and expats have income between 10.000 and 30000 AED per month (55.6\% and $53 \%$ respectively). Most citizen respondents work in a non-tourism related job (44.9\%) versus 5.1\% working in tourism. Foe expats, $(49.5 \%)$ of respondents work in a non-tourism job versus $4.3 \%$ work in tourism related jobs.

Table (2) and (3) looks at the mean values of research constructs. It is shown that both citizens and expats have positive opinions regarding the positive economic and sociocultural impacts of tourism. As per the positive environmental impacts of tourism development, the expats have higher positive perceptions compared to citizens. The citizens are more reluctant and neutral about how tourism benefit and conserve the environment.

As per the negative impacts of tourism development, citizens respondents agree with the negative economic impact of tourism, while expats have neutral opinion about it. Regarding the negative socio-cultural and environmental impacts, citizens have neutral perceptions about them while the expats see that there are no negative socio-cultural or environmental impacts of tourism development. Both citizens and expats agree that tourism's benefits to the UAE people exceed its 
drawbacks and both parties support further tourism activities development by the UAE government.

Table 2: Mean and standard deviation values of study variables

\begin{tabular}{|c|c|c|c|c|}
\hline \multirow[t]{2}{*}{ Variables } & \multicolumn{2}{|c|}{ Citizens } & \multicolumn{2}{|c|}{ Expats } \\
\hline & Mean & Std & Mean & Std \\
\hline Tourism has supported the local economy and increased national income & 4.13 & .866 & 4.41 & 679 \\
\hline Tourism has created many employment opportunities in the community & 3.95 & .964 & 4.36 & .741 \\
\hline Tourism has attracted foreign investment to the country & 4.12 & .904 & 4.29 & .762 \\
\hline $\begin{array}{l}\text { Tourism has helped to improve the standard of living of citizens and } \\
\text { residents alike }\end{array}$ & 3.92 & 1.000 & 3.92 & .886 \\
\hline $\begin{array}{l}\text { Tourism helped to improve the level of public services, such as } \\
\text { education, health, and social and recreational services }\end{array}$ & 3.85 & 1.037 & 3.92 & .859 \\
\hline Tourism has created new business opportunities for local residents & 3.99 & .939 & 4.14 & .824 \\
\hline $\begin{array}{l}\text { Due to the high percentage of expats working in the tourism sector, } \\
\text { tourism has caused a large proportion of income leakage outside the } \\
\text { country }\end{array}$ & 3.76 & .870 & 2.79 & .881 \\
\hline $\begin{array}{l}\text { Tourism has prompted an increase in the prices of many goods and } \\
\text { services }\end{array}$ & 3.84 & .944 & 3.68 & 1.018 \\
\hline Tourism has driven local real-estate prices to increase & 3.90 & .978 & 3.83 & .987 \\
\hline A few locals in this community have benefited from tourism & 3.75 & 1.023 & 3.05 & .974 \\
\hline Tourism has enhanced the image of the UAE globally & 4.37 & .786 & 4.51 & .732 \\
\hline $\begin{array}{l}\text { Tourism has increased interaction and increased cultural exchanges } \\
\text { between residents and tourists }\end{array}$ & 4.22 & .820 & 4.02 & .926 \\
\hline $\begin{array}{l}\text { Tourism has helped boost the quality of services and facilities including } \\
\text { roads, transport, restaurants and shopping centres }\end{array}$ & 4.20 & .853 & 4.33 & .784 \\
\hline $\begin{array}{l}\text { Tourism has increased the recreational facilities available to the } \\
\text { population }\end{array}$ & 4.21 & .814 & 4.27 & .917 \\
\hline $\begin{array}{l}\text { Tourism has increased the pride of the locals in their local Arab / Islamic } \\
\text { culture }\end{array}$ & 3.92 & 1.028 & 3.78 & 1.064 \\
\hline $\begin{array}{l}\text { Tourism encouraged the preservation of a wide range of local cultural } \\
\text { activities such as crafts, arts and music }\end{array}$ & 3.89 & 1.044 & 3.84 & 1.031 \\
\hline Tourism has helped the local residents maintain their ethnic identity & 3.87 & 1.096 & 3.63 & .972 \\
\hline Tourism has helped preserve authentic local traditions & 3.72 & 1.169 & 3.61 & .985 \\
\hline $\begin{array}{l}\text { Tourism has inflicted suffering on residents living in famous tourist } \\
\text { areas }\end{array}$ & 2.90 & 1.077 & 2.82 & .909 \\
\hline $\begin{array}{l}\text { Tourism has encouraged local people to abandon their Emirati culture, } \\
\text { customs and traditions / caused the loss of cultural identity }\end{array}$ & 3.13 & 1.160 & 2.71 & .964 \\
\hline $\begin{array}{l}\text { Tourism has motivated the locals to imitate tourist behaviour and } \\
\text { relinquish Arab / Islamic cultural values }\end{array}$ & 3.07 & 1.162 & 2.78 & .990 \\
\hline $\begin{array}{l}\text { Tourism has limited the use of recreational facilities such as } \\
\text { entertainment and recreational centres, and sport complexes for the local } \\
\text { people }\end{array}$ & 2.90 & 1.189 & 2.42 & .944 \\
\hline $\begin{array}{l}\text { Tourism has contributed to social problems such as crime, drug use, } \\
\text { prostitution, alcoholism, gambling, smuggling, and so on }\end{array}$ & 2.66 & 1.179 & 3.03 & 1.203 \\
\hline Tourism has caused crowding in the streets, places and public services & 2.29 & 1.122 & 3.38 & 1.100 \\
\hline $\begin{array}{l}\text { Tourism has contributed to the preservation of the natural environment } \\
\text { and protection of wildlife }\end{array}$ & 3.71 & 1.060 & 3.58 & .960 \\
\hline Tourism provides an incentive for the restoration of historic buildings & 4.07 & .902 & 3.97 & .809 \\
\hline Tourism helped enhance the country's overall appearance & 4.14 & .842 & 4.28 & .744 \\
\hline Tourism has led the country to implement environmental pra & 3.61 & .903 & 3.71 & .855 \\
\hline
\end{tabular}




\begin{tabular}{|c|c|c|c|c|}
\hline \multirow[t]{2}{*}{ Variables } & \multicolumn{2}{|c|}{ Citizens } & \multicolumn{2}{|c|}{ Expats } \\
\hline & Mean & Std & Mean & Std \\
\hline Now there are fewer natural landscapes and green areas, due to tourism & 2.74 & 1.021 & 2.43 & 1.059 \\
\hline The natural environment has been ruined by tourist infrastructure & 2.70 & 1.046 & 2.35 & 1.013 \\
\hline $\begin{array}{l}\text { The tourist facilities are not in harmony with the natural environment } \\
\text { and the surrounding traditional buildings }\end{array}$ & 2.63 & 1.108 & 2.29 & .924 \\
\hline Tourism has caused air pollution & 3.15 & 1.060 & 2.78 & 1.121 \\
\hline Tourism has caused sea pollution & 3.13 & 1.063 & 2.71 & 1.096 \\
\hline $\begin{array}{l}\text { Tourism has created significant solid waste because of the large number } \\
\text { of tourists }\end{array}$ & 3.38 & 1.109 & 2.86 & 1.135 \\
\hline Tourism has caused noise pollution & 3.44 & 1.109 & 3.00 & 1.206 \\
\hline $\begin{array}{l}\text { Tourism has brought high pressure on the various public services, } \\
\text { consequently reducing their efficiency }\end{array}$ & 3.29 & 1.049 & 2.70 & 1.058 \\
\hline $\begin{array}{l}\text { Overall, I think tourism's benefits to the UAE people exceed its } \\
\text { drawbacks }\end{array}$ & 3.93 & .930 & 4.14 & .781 \\
\hline $\begin{array}{l}\text { The UAE government should step up its efforts to increase the number } \\
\text { of tourists in the future }\end{array}$ & 3.53 & .987 & 3.79 & .902 \\
\hline UAE government should invest more to support tourism development & 4.04 & .846 & 4.01 & .793 \\
\hline $\begin{array}{l}\text { UAE local people should support the tourism development and should } \\
\text { welcome tourist activities }\end{array}$ & 4.11 & .873 & 4.11 & .727 \\
\hline
\end{tabular}

Table 3: Mean values of research constructs

\begin{tabular}{|l|c|c|}
\hline \multicolumn{1}{|c|}{ Constructs } & Citizens (Mean) & Expats (Mean) \\
\hline Tourism positive economic impacts & 3.99 & 4.18 \\
\hline Tourism negative economic impacts & 3.82 & 3.34 \\
\hline Tourism positive socio-cultural impacts & 4.25 & 4.00 \\
\hline Tourism negative socio-cultural impacts & 3.18 & 2.86 \\
\hline Tourism positive environmental impacts & 3.88 & 3.06 \\
\hline Tourism negative environmental impacts & 3.06 & 2.64 \\
\hline Overall evaluation of tourism impacts & 3.93 & 4.14 \\
\hline Support for tourism development & 3.89 & 3.97 \\
\hline
\end{tabular}

\section{Measurement models}

The measurement models look at the validity and reliability of the measurement scale in the study. Table (4) shows that the measurement models for both citizens and expats are valid. Convergent validity exits in both models where average-variance extracted values (AVE) are greater than 0.5 (Hair et al., 2016). Discriminant validity is evident in both models where the square root of AVEs exceed the correlation values among constructs (Kock, 2020). Both models are reliable where the values of both Cronbach's alpha (CA) and composite reliability are greater than the threshold of 0.7 (Field, 2009, Hair et al., 2016).

Table 4: Measurement models

\begin{tabular}{|c|c|c|c|c|c|c|c|c|c|c|c|}
\hline \multirow{2}{*}{ Construct } & \multirow{2}{*}{ Indicators } & \multicolumn{5}{|c|}{ Citizens } & \multicolumn{5}{|c|}{ Expats } \\
\hline & & Loading & $\mathrm{CA}$ & $\mathrm{CR}$ & AVE & $\sqrt{A V E}$ & Loading & CA & CR & AVE & $\sqrt{A V E}$ \\
\hline \multirow{5}{*}{$\begin{array}{l}\text { Positive } \\
\text { economic } \\
\text { impacts }\end{array}$} & $\begin{array}{l}\text { Tourism has supported } \\
\text { the local economy }\end{array}$ & .871 & \multirow{5}{*}{.927} & \multirow{5}{*}{.943} & \multirow{5}{*}{.733} & \multirow{5}{*}{.856} & .867 & \multirow{5}{*}{.864} & \multirow{5}{*}{.899} & \multirow{5}{*}{.601} & \multirow{5}{*}{.775} \\
\hline & $\begin{array}{l}\text { Tourism has created } \\
\text { many job opportunities }\end{array}$ & .852 & & & & & .829 & & & & \\
\hline & $\begin{array}{l}\text { Tourism has attracted } \\
\text { foreign investment }\end{array}$ & .826 & & & & & .809 & & & & \\
\hline & $\begin{array}{l}\text { Tourism has improved } \\
\text { the standard of living }\end{array}$ & .855 & & & & & .742 & & & & \\
\hline & Tourism improved the & .850 & & & & & .621 & & & & \\
\hline
\end{tabular}


International Journal of Heritage, Tourism and Hospitality Vol. (14), No. (1), June, 2020

\begin{tabular}{|c|c|c|c|c|c|c|c|c|c|c|c|}
\hline \multirow{2}{*}{ Construct } & \multirow{2}{*}{ Indicators } & \multicolumn{5}{|c|}{ Citizens } & \multicolumn{5}{|c|}{ Expats } \\
\hline & & Loading & $\mathrm{CA}$ & $\mathrm{CR}$ & AVE & $\sqrt{A V E}$ & Loading & $\mathrm{CA}$ & $\mathrm{CR}$ & AVE & $\sqrt{A V E}$ \\
\hline & level of public services & & & & & & & & & & \\
\hline & $\begin{array}{l}\text { Tourism has created } \\
\text { new business } \\
\text { opportunities }\end{array}$ & .883 & & & & & .758 & & & & \\
\hline \multirow[t]{4}{*}{$\begin{array}{l}\text { Negative } \\
\text { economic } \\
\text { impacts }\end{array}$} & $\begin{array}{l}\text { Tourism caused a large } \\
\text { proportion of income } \\
\text { leakage }\end{array}$ & .836 & \multirow{4}{*}{.860} & \multirow{4}{*}{.906} & \multirow{4}{*}{.707} & \multirow{4}{*}{.841} & .726 & \multirow{4}{*}{.763} & \multirow{4}{*}{.849} & \multirow{4}{*}{.587} & \multirow{4}{*}{.766} \\
\hline & $\begin{array}{l}\text { Tourism has prompted } \\
\text { an increase in the } \\
\text { goods' prices }\end{array}$ & .859 & & & & & .845 & & & & \\
\hline & $\begin{array}{l}\text { Tourism has driven } \\
\text { local real-estate prices } \\
\text { to increase }\end{array}$ & .906 & & & & & .801 & & & & \\
\hline & $\begin{array}{l}\text { A few locals have } \\
\text { benefited from tourism } \\
\text { activities }\end{array}$ & .756 & & & & & .683 & & & & \\
\hline \multirow{8}{*}{$\begin{array}{l}\text { Positive } \\
\text { socio- } \\
\text { cultural } \\
\text { impacts }\end{array}$} & $\begin{array}{l}\text { Tourism has enhanced } \\
\text { the image of the UAE } \\
\text { globally }\end{array}$ & .780 & \multirow{8}{*}{.940} & \multirow{8}{*}{.950} & \multirow{8}{*}{.704} & \multirow{8}{*}{.839} & .603 & \multirow{8}{*}{.887} & \multirow{8}{*}{.910} & \multirow{8}{*}{.561} & \multirow{8}{*}{.749} \\
\hline & $\begin{array}{l}\text { Tourism has increased } \\
\text { cultural exchanges }\end{array}$ & .829 & & & & & .695 & & & & \\
\hline & $\begin{array}{l}\text { Tourism has helped } \\
\text { boost the quality of } \\
\text { services }\end{array}$ & .852 & & & & & .731 & & & & \\
\hline & $\begin{array}{l}\text { Tourism has increased } \\
\text { the recreational } \\
\text { facilities }\end{array}$ & .822 & & & & & .718 & & & & \\
\hline & $\begin{array}{l}\text { Tourism has increased } \\
\text { the pride of the local } \\
\text { culture }\end{array}$ & .873 & & & & & .780 & & & & \\
\hline & $\begin{array}{l}\text { Tourism encouraged the } \\
\text { preservation of local } \\
\text { activities }\end{array}$ & .865 & & & & & .798 & & & & \\
\hline & $\begin{array}{l}\text { Tourism helped } \\
\text { residents maintain their } \\
\text { ethnic identity }\end{array}$ & .850 & & & & & .844 & & & & \\
\hline & $\begin{array}{l}\text { Tourism has helped } \\
\text { preserve authentic local } \\
\text { traditions }\end{array}$ & .837 & & & & & .798 & & & & \\
\hline \multirow{6}{*}{$\begin{array}{l}\text { Negative } \\
\text { socio- } \\
\text { cultural } \\
\text { impacts }\end{array}$} & $\begin{array}{l}\text { Suffering on residents } \\
\text { living in famous tourist } \\
\text { areas }\end{array}$ & .783 & \multirow{6}{*}{.859} & \multirow{6}{*}{.896} & \multirow{6}{*}{.591} & \multirow{6}{*}{.769} & .609 & \multirow{6}{*}{.834} & \multirow{6}{*}{.879} & \multirow{6}{*}{.551} & \multirow{6}{*}{.742} \\
\hline & $\begin{array}{l}\text { Tourism has caused the } \\
\text { loss of cultural identity }\end{array}$ & .760 & & & & & .824 & & & & \\
\hline & $\begin{array}{l}\text { Tourism has motivated } \\
\text { the locals to imitate } \\
\text { tourists }\end{array}$ & .821 & & & & & .786 & & & & \\
\hline & $\begin{array}{l}\text { Limiting the use of } \\
\text { recreational facilities } \\
\text { for locals }\end{array}$ & .828 & & & & & .732 & & & & \\
\hline & $\begin{array}{l}\text { Tourism has } \\
\text { contributed to social } \\
\text { problems }\end{array}$ & .778 & & & & & .800 & & & & \\
\hline & Tourism has caused & 626 & & & & & 681 & & & & \\
\hline
\end{tabular}


International Journal of Heritage, Tourism and Hospitality Vol. (14), No. (1), June, 2020

\begin{tabular}{|c|c|c|c|c|c|c|c|c|c|c|c|}
\hline \multirow{2}{*}{ Construct } & \multirow{2}{*}{ Indicators } & \multicolumn{5}{|c|}{ Citizens } & \multicolumn{5}{|c|}{ Expats } \\
\hline & & Loading & $\mathrm{CA}$ & $\mathrm{CR}$ & AVE & $\sqrt{A V E}$ & Loading & $\mathrm{CA}$ & $\mathrm{CR}$ & AVE & $\sqrt{A V E}$ \\
\hline & $\begin{array}{l}\text { crowding in streets \& } \\
\text { public services }\end{array}$ & & & & & & & & & & \\
\hline \multirow[t]{4}{*}{$\begin{array}{l}\text { Positive } \\
\text { environment } \\
\text { al impacts }\end{array}$} & $\begin{array}{l}\text { The preservation of the } \\
\text { natural environment } \\
\text { and wildlife }\end{array}$ & .782 & \multirow{4}{*}{.852} & \multirow{4}{*}{.901} & \multirow{4}{*}{.695} & \multirow{4}{*}{.833} & .780 & \multirow{4}{*}{.799} & \multirow{4}{*}{.870} & \multirow{4}{*}{.629} & \multirow{4}{*}{.793} \\
\hline & $\begin{array}{l}\text { Tourism incentives the } \\
\text { restoration of historic } \\
\text { buildings }\end{array}$ & .864 & & & & & .875 & & & & \\
\hline & $\begin{array}{l}\text { Tourism enhances the } \\
\text { country's overall } \\
\text { appearance }\end{array}$ & .897 & & & & & .842 & & & & \\
\hline & $\begin{array}{l}\text { Tourism helped to } \\
\text { implement } \\
\text { environmental practices }\end{array}$ & .786 & & & & & .658 & & & & \\
\hline \multirow[t]{8}{*}{$\begin{array}{l}\text { Negative } \\
\text { environment } \\
\text { al impacts }\end{array}$} & $\begin{array}{l}\text { Fewer natural } \\
\text { landscapes and green } \\
\text { areas, due to tourism }\end{array}$ & .693 & \multirow{8}{*}{.910} & \multirow{8}{*}{.927} & \multirow{8}{*}{.616} & \multirow{8}{*}{.785} & .773 & \multirow{8}{*}{.923} & \multirow{8}{*}{.937} & \multirow{8}{*}{.653} & \multirow{8}{*}{.808} \\
\hline & $\begin{array}{l}\text { The natural } \\
\text { environment has been } \\
\text { ruined by tourists }\end{array}$ & .695 & & & & & .802 & & & & \\
\hline & $\begin{array}{l}\text { Tourist facilities are not } \\
\text { in harmony with natural } \\
\text { environment }\end{array}$ & .703 & & & & & .707 & & & & \\
\hline & $\begin{array}{l}\text { Tourism has caused air } \\
\text { pollution }\end{array}$ & .856 & & & & & .876 & & & & \\
\hline & $\begin{array}{l}\text { Tourism has caused sea } \\
\text { pollution }\end{array}$ & .867 & & & & & .893 & & & & \\
\hline & $\begin{array}{l}\text { Tourism has created } \\
\text { significant solid waste }\end{array}$ & .816 & & & & & .830 & & & & \\
\hline & $\begin{array}{l}\text { Tourism has caused } \\
\text { noise pollution }\end{array}$ & .811 & & & & & .811 & & & & \\
\hline & $\begin{array}{l}\text { Tourism has brought } \\
\text { high pressure on public } \\
\text { services }\end{array}$ & .817 & & & & & .757 & & & & \\
\hline Evaluation & $\begin{array}{l}\text { Overall, I think tourism } \\
\text { 's benefits exceed its } \\
\text { drawbacks }\end{array}$ & 1.00 & 1.00 & 1.00 & 1.00 & 1.00 & 1.00 & 1.00 & 1.00 & 1.00 & 1.00 \\
\hline \multirow[t]{3}{*}{$\begin{array}{l}\text { Tourism } \\
\text { development }\end{array}$} & $\begin{array}{l}\text { The UAE should step } \\
\text { up its efforts to increase } \\
\text { Tourists' number }\end{array}$ & .733 & \multirow{3}{*}{.818} & \multirow{3}{*}{.894} & \multirow{3}{*}{.739} & \multirow{3}{*}{.860} & . 862 & \multirow{3}{*}{.896} & \multirow{3}{*}{.936} & \multirow{3}{*}{.829} & \multirow{3}{*}{.911} \\
\hline & $\begin{array}{l}\text { UAE should invest } \\
\text { more to support tourism } \\
\text { development }\end{array}$ & .917 & & & & & .929 & & & & \\
\hline & $\begin{array}{l}\text { UAE local people } \\
\text { should support tourism } \\
\text { development }\end{array}$ & .916 & & & & & .939 & & & & \\
\hline
\end{tabular}

Note: $\mathrm{CA}=$ Cronbach's alpha, $\mathrm{CR}=$ Composite reliability, $\mathrm{AVE}=$ average-variance extracted.

Citizen's Model fit indices: $\mathrm{APC}=0.260, \mathrm{P}<0.001$, ARS $=0.513, \mathrm{P}<0.001$, AARS $=0.505, \mathrm{P}<0.001$, AVIF $=2.481$, ideal, AFVIF=2.556, ideal, $\mathrm{GoF}=0.609$, large, $\mathrm{SPR}=0.857$, acceptable, RSCR=0.990, acceptable, $\mathrm{SSR}=1.000$, acceptable, and NLBCDR $=0.714$, acceptable.

Expats' Model fit indices: APC $=0.225, \mathrm{P}=0.001, \mathrm{ARS}=0.479, \mathrm{P}<0.001, \mathrm{AARS}=0.465, \mathrm{P}<0.001$, AVIF $=1.485$, ideal, $\mathrm{AFVIF}=1.833$, ideal, $\mathrm{GoF}=0.569$, large, $\mathrm{SPR}=0.857$, acceptable, $\mathrm{RSCR}=1.000$, ideal, $\mathrm{SSR}=1.000$, acceptable, and NLBCDR $=0.714$, acceptable 


\section{Analysis technique}

The study employs structural equation modelling (SEM) for testing hypotheses. The WarpPLS version (7) was used for data analysis. The measurement model was evaluated via the model fit indices. The validity and reliability of the measurement model was measured using the recommended thresholds of average variance extracted (AVE) (Kock, 2020) and Cronbach's alpha and composite reliability (Hair et al., 2016).

\section{Structural model}

The structural model aims to test the hypotheses of the study. Looking at Figure (1), it is clear that the first hypothesis is supported by both citizens $(\beta 1=.27$ and $\mathrm{p}<0.01)$ and expats $(\beta 2=.40$ and $\mathrm{p}<0.01)$. However, the expats have stronger perceptions for the positive economic impacts of tourism.

While citizens believe that tourism has negative economic impacts $(\beta 1=.18$ and $\mathrm{p}<0.01, \mathrm{H} 2$ is supported), expats do not believe in these negative impacts $(\beta 2=-0.01$ and $p>0.05$ and $\mathrm{H} 2$ is not supported for expats). As for socio-cultural impacts of tourism, both citizens $(\beta 1=.25$ and $\mathrm{p}<0.01)$ and expats $(\beta 2=.24$ and $\mathrm{p}<0.01)$ believe that tourism has positive socio-cultural impacts (the third hypothesis is supported) and both categories perceive that tourism has no negative socio-cultural impacts on UAE society $(\beta 1=-0.04$ and $p>0.05$ for citizens) and $(\beta 2=-0.02$ and $\mathrm{p}>0.05$ ) (the fourth hypothesis is supported).

Looking at the environmental impacts of tourism, both citizens $(\beta 1=.30$ and $p<0.01)$ and expats $(\beta 2=.19$ and $p<0.01)$ believe that tourism has positive environmental impacts of tourism on the UAE society (the fifth hypothesis is supported). However, citizens believe that there are some negative environmental impacts of tourism $(\beta 1=-.14$ and $\mathrm{p}<0.05)$ (the sixth hypothesis is supported), but expats believe there are no negative impact of tourism on environment $(\beta 2=-.06$ and $\mathrm{p}>0.05$ ) (the sixth hypothesis is not supported for them).

The perceptions of citizens of the positive and negative impacts of tourism economically, socially, and environmentally explain $62 \%$ of their perception of their overall evaluation of tourism impacts, meanwhile, the perceptions of expats explain $49 \%$ of their overall evaluation of tourism impacts on the UAE society. Findings reveal that the overall positive evaluation of tourism impacts is significantly affect the residents' support for tourism development by the UAE government $(\beta 1=.64$ and $p<0.01$ for citizens and $\beta 2=.68$ and $p<0.01$ for the expats, the seventh hypothesis is supported).

Figure 1: Structural models for citizens and expats

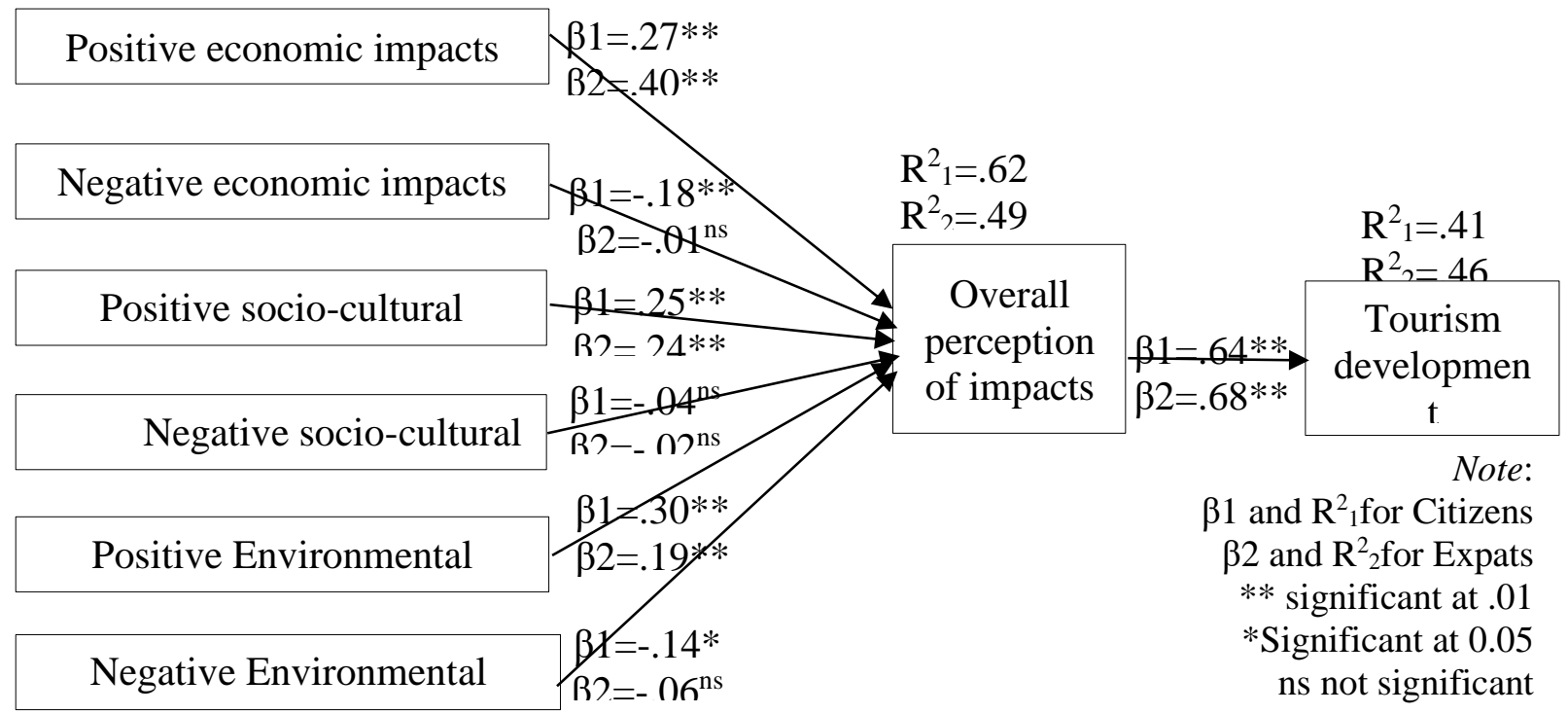




\section{Discussion and implications}

This study investigates residents' perceptions regarding the tourism impacts in UAE where the majority of the population are expatriates. The results of the study reveal a positive association between residents' perceptions of positive economic, socio-cultural, and environmental impacts of tourism and their support for tourism development. The citizens reported greater perceived impacts of the negative economic and environmental impacts of tourism whereas the expatriate residents did not perceive any negative impacts of tourism of any kind (economic, sociocultural, environmental). Both groups perceived the effects of the positive socio-cultural impacts positively while both groups reported no negative socio-cultural impacts.

Another significant finding of the study is that although the national residents perceived the negative economic and environmental impacts of tourism development, this has no effect on their overall evaluation of tourism impacts or on their support for tourism development. This finding is really noteworthy and contradicts with Hammad et al. (2019) study in which results suggest a negative relationship between residents' negative perceptions of social, environmental, and economic impacts of tourism and their support for tourism development in the UAE. The possible explanation for this contradiction between the two studies may be the collapse of tourism revenues because of the COVID- 19 pandemic that made the people recognize the benefits of tourism development on the society more positively than its costs. However, a study by Miyakuni (2012) reported similar results of no relationship between residents' negative perceptions of the economic impacts of tourism and their support for tourism development on Iriomote Island, Japan.

Expats expressed greater positive perceptions of the economic impacts of tourism. This finding goes on line with the Papastathopoulos et al., (2020); Hammad et al., (2017) and Hammad et al. (2019) studies who also found that expats have more positive perceptions of the economic impacts of tourism, while national residents have more concerns regarding the social, cultural, and environmental impacts of tourism. One possible reason is that expats are attracted to live in the UAE mainly in search of better economic opportunities; therefore, they would be more concerned about the economic impact while the nationals are more anxious about their country's social, cultural and environmental impacts. Nevertheless, the results of this study contradict Papastathopoulos et al., (2020); Hammad et al., (2017) and Hammad et al. (2019) studies in the way it found that both local and expats perceive the positive socio- cultural aspects of tourism development while both do not perceive any negative socio- cultural aspects of tourism. Remarkably, both residents' groups (citizens and expats) showed positive overall evaluation of tourism impacts and both supported future tourism development by UAE government.

Reaching such results during the pandemic of Covid-19 and the collapse of the domestic and the international tourist demand emphasizes the effective role tourism industry plays in the UAE economy. It also indicates the awareness and consciousness of the population (national and expats) of the positive impact of tourism on their society that reflected on their support for this economic activity under all circumstances.

This research made theoretical contributions to the literature, as it is an empirical work undertaken to validate the findings of previous studies that examined residents' views of tourism's economic, socio-cultural and environmental impacts in the UAE. The research can also be considered one of the pioneering studies to evaluate the effect of the epidemic on people's perceptions of tourism impacts.

The study offers a contribution to tourism planners to guide them gain the residents' support for tourism development policies. To meet the economic concerns of residents, tourism stakeholders and policymakers can offer tourism activities at discounted rates for residents, or through 
promotional packages. This will allow the residents (citizens and expats) to appreciate tourism activities more and be more supportive to further tourism projects. An additional reduction in tourism activities prices for residents should be applies during off-seasons, especially during summer. Providing training to nationals to encourage them to work in the tourism industry would also increase the economic benefits that nationals receive from tourism, and thereby improve perceptions of tourism's impacts.

Planners and policymakers must address the concerns of all residents, as they represent a major participant in the development of tourism. They need to gather more information on the residents' attitude towards tourism using public discussions, surveys, and focus groups. In addition, residents should be directly involved in the tourism planning process in order to ensure their support for the development of tourism and to avoid any problems that may arise in the future. Planners and policy makers should work to increase citizens' awareness of the benefits of investing in tourism and encourage them to participate in tourism investment by providing investment facilities to residents who wish to invest their money in tourism. The government should provide technical and logistical support to the local investors and reduce taxes on investment in tourism projects. This will enhance people's sense of tourism benefits and decrease their sense of tourism costs, thereby increasing their support for the development of tourism.

Planners and suppliers of tourism must encourage citizens to join work in the field of tourism and to cooperate with educational institutions to qualify citizens to be able to work in the field of tourism. This process should begin with academic guidance for high school students to urge them to join the tourism specialization at the university level. The increase in the number of citizens working in the tourism sector will ensure their continuous support for the development of tourism in the country. On the other hand, planning for the development of tourism enterprises should consider citizens' misgivings about the negative effects of tourism on the environment. Tourism projects must be developed in a sustainable manner that preserves the natural and cultural environment in order to ensure that the development of tourism is supported by society, in particular by citizens.

\section{References}

Agence France-Presse (AFP) (2020). Dubai announces record tourism arrivals in 2019, accessed online at: https://www.thejakartapost.com/travel/2020/01/22/dubai-announces-recordtourism-arrivals-in-2019-.html / Accessed (6/5/2020)

Al Asoomi, M., (2015). How diversification drives the UAE economy, accessed online at: https://gulfnews.com/business/analysis/how-diversification-drives-the-uae-economy$1.1630352 /($ Accessed 15/5/2020)

Almeida-García, F., Fernandez, M., Balbuena-Vázquez, A. \& Cortés-Macias, R. (2016). Residents' perceptions of tourism development in Benalmadena (Spain), Tourism Management, 54, 259-274.

Ap, J. (1992). Resident's perceptions on tourism impacts, Annals of Tourism Research, 19(4), 665-690.

Brunt, P, \& Courtney, P. (1999). Host Perceptions of Sociocultural Impacts, Annals of Tourism Research, 26 (3), 493-515.

Diedrich, A., \& García, E. (2009). Local perceptions of tourism as indicators of destination decline. Tourism Management, 30, 512-521.

Dyer, P., Gursoy, D., Sharma, B., \& Carter, J. (2007). Structural modeling of resident perceptions of tourism and associated development on the Sunshine Coast, Australia. Tourism Management, 28, 409- 422. 
Emirates News Agency (2019). Tourism sector contributes AED164.7 bn to GDP in 2018: Ministry of Economy accessed online at: http://www.wam.ae/en/details/1395302790063 / (Accessed 23/2/2020)

Field, A. (2009). Discovering statistics using SPSS, London, Sage Publications Ltd.

Hair, J., Hult, G., Ringle, C. \& Sarstedt, M. (2016). A primer on partial least squares structural equation modeling (PLS-SEM), Sage Publications.

Hale, C. \& Kozak, N. (2017). The tourism industry in Cappadocia: A Social Exchange Theory approach. Asia Pacific Journal of Tourism Research, 22 (3), 284-300.

Hammad, N., Ahmad, S.\& Papastathopoulos, A. (2017). Evaluating perceptions of residents' towards impacts of tourism development in Emirates of Abu Dhabi, United Arab Emirates. Tourism Review, 2(4), 448-46.

Hammad, N., Ahmad, S.\& Papastathopoulos, A. (2019), The moderating role of nationality in residents' perceptions of the impacts of tourism development in the United Arab Emirates. International Journal of Tourism Research, 21, 61-75.

Kock, N. (2020). WarpPLS user Manual: Version 7.0, Laredo, TX, ScriptWarp Systems.

Kumar, A. (2018). 91\% expats in UAE workforce: Experts call for Emiratisation Ashwani. Khaleej Times, accessed online at: https://www.khaleejtimes.com/nation/abu-dhabi/91expats-in-uae-workforce-experts-call-for-emiratisation-- / (Accessed 1/5/2020)

Li, W. \& Bai, Xuemei (2005). A Residential Survey on Urban Tourism Impacts in Harbin, China. Tourism Research, 1(1), 116-129.

Long, P. \& Kayat, K. (2011). Residents' perceptions of tourism impact and their support for tourism development: the case study of Cuc Phuong National Park, Ninh Binh province, Vietnam. European Journal of Tourism Research, 4 (2), 123-146.

Lundberg, E. (2017), The importance of tourism impacts for different local resident groups: A case study of a Swedish seaside destination. Journal of Destination Marketing \& Management, 6, 46-55.

Mastercard (2019). Dubai Remains One of The World's Most Visited Cities: Mastercard Global Destination Cities Index 2019, available at:

https://newsroom.mastercard.com/mea/press-releases/dubai-remains-one-of-the-worlds-mostvisited-cities-mastercard-global-destination-cities-index-2019/ (Accessed 2/4/2020)

Miyakuni, K. (2012). Residents' attitudes toward tourism, focusing on ecocecentric attitudes and perceptions of economic costs: The case of Iriomote Island. Japan (doctoral dissertation). Michigan State University, USA.

Mohammadi, M., Khalifah, Z. \& Hosseini, H. (2010). Local People Perceptions toward Social, Economic and Environmental Impacts of Tourism in Kermanshah (Iran). Asian Social Science, 6(11), 220-225.

Mubasher (2020). UAE's int'l tourism revenue expected to drop by $70 \%$ on COVID-19, accessed online at: https://english.mubasher.info/news/3653479/UAE-s-int-l-tourism-revenueexpected-to-drop-by-70-on-COVID-19/ (Accessed 30 Mai, 2020)

Nyaupane, G., Lew, A. \& Tatsugawa, K. (2014). Perceptions of trekking tourism and social and environmental change in Nepal's Himalayas. Tourism Geographies, 16 (3), 415-437, DOI: 10.1080/14616688.2014.942233

Özel, C. \& Kozak, N. (2017). An exploratory study of resident perceptions toward the tourism industry in Cappadocia: a Social Exchange Theory approach, Asia Pacific Journal of Tourism Research, 22 (3), 284-300. 
Papastathopoulos, A., Ahmad, S., Al Sabri, N. \& Kaminakis, K., (2020). Demographic Analysis of Residents' Support for Tourism Development in the UAE: A Bayesian Structural Equation Modeling Multigroup Approach. Journal of Travel Research, 59(6), 1119-1139.

Rasoolimanesh, S., Jaafar M., Kock, N. \& Ramayah, T. (2015). A Revised Framework of Social Exchange Theory to Investigate the Factors Influencing Residents' Perceptions. Tourism Management Perspectives, 16, 335-45.

Rezaei, N. (2017). Resident perceptions toward tourism impacts in historic center of Yazd, Iran. Tourism Geographies, 19(5), 734-755, DOI: 10.1080/14616688.2017.1331261

Simao, J.\& Mosso, A. (2013). Residents' perceptions towards tourism development: the case of Sal Island. International Journal of Development Issues, 12(2), 140-157.

Singh, R. (2013), Residents' Perceived Impacts of Tourism: A Case of Manali (Himachal Pradesh), International Journal of Marketing and Technology, 3(4), 2249-1058.

Stylidis, D., Biran, A., Sit, J. \& Szivas, E. (2014). Residents' support for tourism development: The role of residents' place image and perceived tourism impacts. Tourism Management, 45, 260-274.

Stylidis, D., Biran, A., Sit, J., \& Szivas, E. M. (2014). Residents' support for tourism development: the role of residents' place image and perceived tourism impacts. Tourism Management, 45, 260-274.

Sutton, J. (2016). From desert to destination: Conceptual insights into the growth of events tourism in the United Arab Emirates. Anatolia, 27(3), 352-366.

Travel and tourism competitiveness report, 2017; Middle East and North Africa results, accessed online at: https://reports.weforum.org/travel-and-tourism-competitiveness-report2017/middle-east-and-north-africa-results/ (Accessed 6/5/2020)

Turak, N. (2020). 70\% of Dubai companies expect to go out of business within six months due to coronavirus pandemic, survey says, accessed online at: https://www.cnbc.com/2020/05/21/coronavirus-dubai-70percent-of-companies-expect-toclose-in-six-months.html / (Accessed 21 May 2020)

Ukaegbu, M., Carr, N. \& Okpoko, P. (2019). Local people's perceptions of the potential implications of cultural revitalisation through tourism in Benin, Nigeria. Journal of Tourism and Cultural Change, 18(4), 455-469. https://doi.org/10.1080/14766825.2019.1702992

UNWTO, 2017. Tourism Key for Economic Growth and Diversification in the MENA Region. Madrid: UNWTO, accessed online at: http://media.unwto.org/ press-release/2017-0425/tourism-key-economic-growth-and- diversification-mena-region / (Accessed 03/2/2020)

Woosnam, K., Maruyama, N., Ribeiro, M. \& Joo, D. (2019). Explaining minority residents' attitudes of ethnic enclave tourism from general perceptions of tourism impacts. Journal of Tourism and Cultural Change, 17(4), 467-484.

World Travel and Tourism Council (2017), Travel \& Tourism Economic Impact - United Arab Emirates; London, United Kingdom. 